University of Nebraska - Lincoln

DigitalCommons@University of Nebraska - Lincoln

Socio-demographic and drug use factors associated with HIV-1 recombinants and dual infections in Northern Thai drug users: Associations of risk with genetic complexity

G. H. Kijak

US Military HIV Research Program, drkijak@gmail.com

C. Beyrer

Johns Hopkins Bloomberg School of Public Health

S. Tovanabutra

US Military HIV Research Program

T. Sripaipan

Johns Hopkins Bloomberg School of Public Health

V. Suriyanon

Research Institute for Health Sciences

See next page for additional authors

Follow this and additional works at: https://digitalcommons.unl.edu/usarmyresearch

Part of the Operations Research, Systems Engineering and Industrial Engineering Commons

Kijak, G. H.; Beyrer, C.; Tovanabutra, S.; Sripaipan, T.; Suriyanon, V.; Moqueet, N.; Sanders-Buell, E.; Saokhieo, P.; Timpan, U.; Jittiwutikarn, J.; Robb, M. L.; Birx, D. L.; Celentano, D. D.; and McCutchan, F. E., "Socio-demographic and drug use factors associated with HIV-1 recombinants and dual infections in Northern Thai drug users: Associations of risk with genetic complexity" (2010). US Army Research. 133. https://digitalcommons.unl.edu/usarmyresearch/133

This Article is brought to you for free and open access by the U.S. Department of Defense at DigitalCommons@University of Nebraska - Lincoln. It has been accepted for inclusion in US Army Research by an authorized administrator of DigitalCommons@University of Nebraska - Lincoln. 


\section{Authors}

G. H. Kijak, C. Beyrer, S. Tovanabutra, T. Sripaipan, V. Suriyanon, N. Moqueet, E. Sanders-Buell, P. Saokhieo, U. Timpan, J. Jittiwutikarn, M. L. Robb, D. L. Birx, D. D. Celentano, and F. E. McCutchan 
Full length article

\title{
Socio-demographic and drug use factors associated with HIV- 1 recombinants and dual infections in Northern Thai drug users: Associations of risk with genetic complexity
}

\author{
G.H. Kijak ${ }^{a}, *$, C. Beyrer ${ }^{b}$, S. Tovanabutra ${ }^{a}$, T. Sripaipan ${ }^{b}$, V. Suriyanon ${ }^{c}$, N. Moqueet $^{a}$, \\ E. Sanders-Buell a , P. Saokhieo ${ }^{c}$, U. Timpan $^{c}$, J. Jittiwutikarn ${ }^{\text {d }}$, M.L. Robb ${ }^{\text {a }}$, D.L. Birx ${ }^{\mathrm{e}, 1}$, \\ D.D. Celentano ${ }^{\mathrm{b}}$, F.E. McCutchan ${ }^{\mathrm{a}, 2}$
}

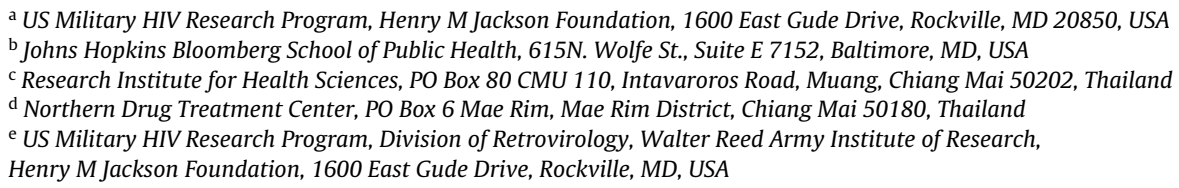

\section{A R T I C L E I N F O}

\section{Article history:}

Received 27 November 2009

Received in revised form 29 October 2010

Accepted 8 November 2010

Available online $\mathrm{xxx}$

\section{Keywords:}

Injection drug use

HIV/AIDS

Recombination

Dual infection

Molecular epidemiology

Injecting risk

Thailand

Multi-region hybridization assay

\begin{abstract}
A B S T R A C T
Background: Dual infection with diverse HIV strains can foster the emergence of recombinants. The resulting increase in viral genetic diversity is a major challenge for vaccine development HIV treatment. In this study we aim to investigate the socio demographic factors associated with an increasing level of genetic diversity among HIV strains in a population of drug-users in Northern Thailand.

Methods: From 1999 through 2000, 2231 volunteers were enrolled in the Opiate-Users Research in Chiang Mai, Thailand. HIV subtype analysis was conducted among those HIV-1 seropositive $(n=347)$ using a multi-region hybridization assay. Social and demographic variables were assessed using a structured questionnaire.

Results: Overall, 336/347 (96.8\%) of the samples could be typed. 81.8\% were CRF01_AE, 3.9\% were subtype B, 9.2\% were recombinants (mostly between CRF01 AE and B) and 5.1\% were dual infections. Dual infections were more frequent among those with a lower education level (AOR: 5.2; 95\% CI 1.4-20.3), those who have initiated injecting in the last 3 years (AOR: 3.9; 95\% CI 1.1-14.6), and those reporting frequent needle sharing in the last 3 months (AOR: 7.0; 95\% CI 1.5-34.1). Both recombinant strains and dual infection were more frequent among those reporting frequent needle sharing in the last 3 months (AOR: 5.3; 95\% CI 1.6-17.1).

Conclusion: To limit the expanding complexity of HIV-1 strains, early intervention should be aimed at reduction in needle sharing, especially among new intravenous drug users.
\end{abstract}

(c) 2010 Elsevier Ireland Ltd. All rights reserved.

\section{Introduction}

Human immunodeficiency virus type 1 (HIV-1) is characterized by extensive and expanding genetic diversity. To date, 9 subtypes within the group $M$ radiation have been described, and many more inter-subtype recombinants have been reported (Kuiken et al.,

\footnotetext{
* Corresponding author at: US Military HIV Research Program, Henry M Jackson Foundation, Rockville, 1600 East Gude Drive Rockville, MD 20850, USA. Tel.: +1 301251 5046; fax: +1 3017627460 .

E-mail address: drkijak@gmail.com (G.H. Kijak).

1 Present address: Centers for Disease Control and Prevention, Atlanta, GA, USA

2 Present address: Bill and Melinda Gates Foundation, Seattle, WA, USA
}

2009). Recombinant strains are believed to emerge after dual infections within multiply-exposed individuals (Ramos et al., 2002; Taylor et al., 2008). While some of these recombinant strains have been retrieved from only one patient ("unique recombinant forms" or URFs), other recombinants have spread into populations ("circulating recombinant forms" or CRFs) (Taylor et al., 2008). By combining pre-existing beneficial mutations, recombination can accelerate the escape from host immune responses and recent studies suggest that HIV-1 envelope has adapted to evade such responses at population levels (Bunnik et al., 2010). For this reason, HIV dual infection and recombination pose major challenges to vaccine design and can hinder the evaluation of the success of efficacy trials. Dual infection has been associated with accelerated disease progression (reviewed by Smith et al., 2005) and increas-

0376-8716/\$ - see front matter @ $\odot 2010$ Elsevier Ireland Ltd. All rights reserved. doi:10.1016/j.drugalcdep.2010.11.013

This article is a U.S. government work, and is not subject to copyright in the United States 
ing genetic diversity has also been linked to anti-retroviral drug resistance, suggesting that diversity may also play roles in HIV therapeutic outcomes (Djoko et al., 2010). Identifying individuals and sub-groups of populations where dual infections are more frequent and recombinant forms are more likely to arise could help in the design and targeting of preventive interventions aimed at diminishing HIV-1 genetic complexity. Little work has been done on the injection drug use behaviors and practices that might contribute to multiple exposure and dual infection among injecting and non-injecting drug users.

The molecular epidemiology of HIV-1 in Thailand has substantially changed over the past two decades. From the late 1980s until the mid 1990s, HIV-1 strains were segregated by risk group, as subtype B predominated among injecting drug users (IDUs), while CRF01_AE was the major form circulating among those with heterosexual exposure (Subbarao et al., 1998). A change in the proportions of clades was seen in the mid 1990s, when CRF01 AE overtook subtype B among IDUs, while still constituting the major clade being transmitted through heterosexual contact (Tovanabutra et al., 2004; Vanichseni et al., 2001). CRF01_AE was also the predominant clade identified among male sex workers in Northern Thailand (Beyrer et al., 1997). Subsequently, our group reported on the emergence of novel recombinant HIV-1 strains between CRF01 AE and subtype B, which were thought to have emerged in successive rounds of dual infection and transmission among multiply-exposed individuals. By the early 2000s, more than half of new infections among IDUs in Northern Thailand were caused by B/CRF01_AE URFs (Tovanabutra et al., 2004), marking a substantial increase in genetic complexity. Moreover, B/CRF01_AE recombinants were also found in contemporary samples from the general population, and two new CRFs, CRF15_01B (Tovanabutra et al., 2001) and CRF34_01B (Tovanabutra et al., 2007), were found in multiple individuals, some with heterosexual risk factors and some others with IDU risk factors and, presumably, some individuals with dual risks for HIV acquisition and transmission. As the Thai epidemic matured, the emergence of these subtypes confirmed increasing genetic diversity, and also established the bridging of IDU and general population HIV-1 variants at molecular levels. Non-injecting drug users in Thailand predominantly use variants of methamphetamine ( $\mathrm{YaBa}$, or "crazy medicine", in Thai), which is generally smoked, not injected. Their demographic and HIV risks vary markedly from IDU and we have previously reported on their lower HIV rates in this cohort (Beyrer et al., 2004).

The Northern region of Thailand, including provinces adjacent to the Golden Triangle in the border with Burma (Myanmar) and Laos, has borne the brunt of the Thai HIV-1 epidemic since its onset. By 2003 , this region, that represented only $8 \%$ of the country's total population, was home to more than $25 \%$ of the AIDS cases (Deewong and Jitnumshap, 2003). The Northern Thai epidemic was marked by both sexual and IDU components, and by the region's extensive commercial sex industry-largely employing sex workers from impoverished Burma, and by high rates of methamphetamine use among adolescents and young adults.

The objective of this study was to evaluate the HIV-1 genetic diversity among sero-positive drug users, both injecting and noninjecting, seeking detoxification at the Chiang Mai Drug Treatment Center (CMDTC), Mae Rim, Thailand, which serves 17 provinces in the northern region. Behavioral and social/demographic variables and drug use practices were investigated for associations with increasing complexity of HIV-1 strains.

\section{Methods}

\subsection{Population under study}

The Opiate-Users Research (OUR) Study was conducted among 2231 volunteers seeking detoxification at the Chiang Mai Drug Treatment Center (CMDTC), Mae Rim,
Thailand. The first phase of the study (February 1999-January 2000) included volunteers admitted for opioid or methamphetamine dependence, and the second phase of the study (February 2000-December 2000) included only IDUs admitted for drug dependence. Inclusion criteria included being 13 years of age or older, provision of informed consent, admission for substance use dependence, agreement to submit to pre- and post-test HIV counseling and venipuncture for HIV serology and HIV subtyping, and completion of a behavioral questionnaire, which was administered in a confidential face-to-face interview. Detailed methods and findings from this study have been previously published elsewhere (Cheng et al., 2006; Razak et al., 2003). The study was approved by the institutional review boards of the Royal Thai Ministry of Public Health, Research Institute of Health Sciences, Chiang Mai University and the Johns Hopkins University. Since persons aged 13-18 were admitted to the drug treatment centers with parental or guardian consent, they were deemed eligible for recruitment into this study if parental consent and individual adolescent assent were obtained and this was approved by all relevant IRBs.

\subsection{HIV-1 serology}

Specimens were tested for HIV antibodies by ELISA using licensed commercially available reagents (Vironostica HIV Uni-form II plus 0; Organon Teknika). Reactive ELISA specimens were tested with the gel-particle agglutination (GPA) test for antibodies to HIV (Serodia-HIV; Fujirebio, Japan). Specimens testing positive in both antibody tests were considered HIV positive. GPA-nonreactive specimens were confirmed by Western blot analysis using licensed commercially available reagents (HIV Blot 2.2; Genelabs Diagnostics, Singapore).

\subsection{HIV-1 subtyping}

Viral RNA was extracted from serum samples by robotic extraction (MagnaPure, Roche Diagnostics). The presence of subtypes B, C, and CRF01_AE, and recombinants and dual infections combining these strains was evaluated using a multi-region hybridization assay (MHAbce v2) as previously published (Tovanabutra et al., 2007). Briefly, after PCR-amplification 8 regions throughout the HIV genome (p17 in gag protease, reverse transcriptase, and integrase in pol; the first exon of tat; gp120 and gp41 in env; and nef) with universal primers, their subtype was assessed in real-time PCRs with respective fluorescent TaqMan probes specific for subtypes $B$ C and CRF01_AE. Samples with concordant patterns of probe reactivity throughout the genome were assigned to the corresponding subtype or CRF, while those samples showing discordant patterns of probe reactivity were considered intersubtype recombinants. Patients with samples exhibiting dual-probe reactivity in the same genome region were considered as dually infected after verification by cloning and real-time PCR subtyping of at least 20 clones per sample. Only samples showing probe reactivity in 4 genome regions or more were considered as typed.

\subsection{Statistical methods}

HIV-1 infections were classified into 9 different genotypes: subtype $B$ subtype C; CRF01_AE; B/CRF01_AE Recombinant; C/CRF01_AE Recombinant; B/C Recombinant; B/CRF01_AE Dual; C/CRF01_AE Dual; and B/C Dual. Single infections were defined as the presence of subtypes B, C, or CRF01_AE, or any of the recombinant genotypes. Dual infections were defined as the presence of B/CRF01_AE Dual; C/CRF01_AE Dual; and B/C Dual genotypes following the accepted classification used elsewhere (Arroyo et al., 2005, 2006, 2009; Herbinger et al., 2006; Hoelscher et al., 2002; Kijak et al., 2007; Saathoff et al., 2010).

Exposure variables of interest included: socio-demographics (age, ethnicity education, occupation, marital status, and residence); incarceration; injection risks and practices (time since first injection, frequency of injection, needle and injection equipment sharing); and sexual risks (lifetime number of sex partners, sex with a female sex worker, sex with another man for male IDU, and STD diagnoses and prior history of STD).

Differences in the distribution of dual HIV infection across variables of interest were assessed using the chi-square test and Fisher's Exact test (if expected cell count was less than 5) for categorical variables, and the Wilcoxon rank sum test for continuous variables. Continuous variables were also categorized based on quartiles and further analyzed as categorical variables. Logistic regression was used to obtain crude odds ratios and $95 \%$ confidence intervals. Due to small numbers observed in some genotypes, multivariate models were not built; however, because age and education level appeared to differ across genotypes, as well as be closely related to other variables of interest, logistic regression was used to obtain ageadjusted and education-adjusted odds ratios and $95 \%$ confidence intervals for those variables with a significance level $\leq 0.10$ in the crude analysis. All statistical analyses were conducted using SAS for Windows version 9.1 (SAS Institute Inc, Cary, NC). 
Table 1

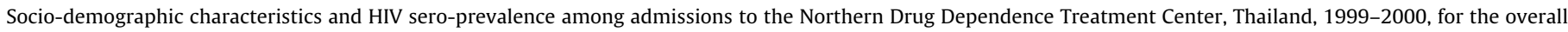
OUR prevalence study population $(N=2231)$.

\begin{tabular}{|c|c|c|c|c|c|c|c|c|c|}
\hline \multirow[t]{2}{*}{ Characteristic } & \multicolumn{3}{|l|}{ Total } & \multicolumn{3}{|l|}{ Male } & \multicolumn{3}{|l|}{ Female } \\
\hline & No. tested & $\begin{array}{l}\text { No. HIV } \\
\text { positive (\%) }\end{array}$ & OR $(95 \% \mathrm{CI})^{*}$ & No. tested & $\begin{array}{l}\text { No. HIV } \\
\text { positive (\%) }\end{array}$ & OR $(95 \% \mathrm{CI})^{*}$ & No. tested & $\begin{array}{l}\text { No. HIV } \\
\text { positive (\%) }\end{array}$ & OR $(95 \% \mathrm{CI})^{*}$ \\
\hline Total & 2231 & $347(15.6)$ & & 2005 & $324(16.2)$ & & 226 & $23(10.2)$ & \\
\hline \multicolumn{10}{|l|}{ Ethnicity } \\
\hline $\begin{array}{l}\text { Ethnic } \\
\text { minority }\end{array}$ & 993 & $117(11.8)$ & 1.0 & 840 & $104(12.4)$ & 1.0 & 153 & $13(8.5)$ & 1.0 \\
\hline Thai & 1238 & $230(18.6)$ & $1.7(1.3-2.2)$ & 1165 & $220(18.9)$ & $1.7(1.3-2.1)$ & 73 & $10(13.7)$ & $1.7(0.7-4.1)$ \\
\hline \multicolumn{10}{|l|}{ Age } \\
\hline $15-23$ years & 788 & $89(11.3)$ & $1.0(0.7-1.3)$ & 717 & $82(11.4)$ & $1.0(0.7-1.3)$ & 71 & $7(9.9)$ & $1.0(0.4-2.9)$ \\
\hline $24-29$ & 368 & $99(26.9)$ & $2.8(2.0-3.9)$ & 345 & $95(27.5)$ & $2.8(2.0-3.9)$ & 23 & $4(17.4)$ & $2.0(0.6-7.2)$ \\
\hline $30-34$ & 323 & $72(22.3)$ & $2.2(1.6-3.1)$ & 298 & $70(23.5)$ & $2.3(1.6-3.2)$ & 25 & $2(8.0)$ & $0.8(0.2-4.1)$ \\
\hline $35+$ & 752 & $87(11.6)$ & 1.0 & 645 & $77(11.9)$ & 1.0 & 107 & $10(9.4)$ & 1.0 \\
\hline \multicolumn{10}{|l|}{ Marital status } \\
\hline Married & 930 & $88(9.5)$ & 1.0 & 804 & $78(9.7)$ & 1.0 & 126 & $10(7.9)$ & 1.0 \\
\hline $\begin{array}{l}\text { Never } \\
\text { married }\end{array}$ & 950 & $163(17.2)$ & $2.0(1.5-2.6)$ & 908 & $161(17.7)$ & $2.0(1.5-2.7)$ & 42 & $2(4.8)$ & $0.6(0.1-2.8)$ \\
\hline $\begin{array}{l}\text { Separated/ } \\
\text { divorced/ } \\
\text { widowed }\end{array}$ & 351 & $96(27.3)$ & $3.6(2.6-5.0)$ & 293 & $85(29.0)$ & $3.8(2.7-5.4)$ & 58 & $11(19.0)$ & $2.7(1.1-6.8)$ \\
\hline \multicolumn{10}{|l|}{ Education level } \\
\hline $\begin{array}{l}\text { Primary } \\
\text { school or } \\
\text { less }\end{array}$ & 1011 & $174(17.2)$ & $1.3(1.0-1.6)$ & 942 & $165(17.5)$ & $1.2(0.95-1.5)$ & 69 & $9(13.0)$ & $1.5(0.6-3.7)$ \\
\hline $\begin{array}{l}\text { Secondary } \\
\text { school or } \\
\text { more }\end{array}$ & 1220 & $173(14.2)$ & 1.0 & 1063 & $159(15.0)$ & 1.0 & 157 & $14(8.9)$ & 1.0 \\
\hline \multicolumn{10}{|l|}{ Occupation } \\
\hline Student & 243 & $6(2.5)$ & 1.0 & 219 & $5(2.3)$ & 1.0 & 24 & $1(4.2)$ & 1.0 \\
\hline Farmer & 865 & $92(10.6)$ & $4.7(2.0-10.9)$ & 779 & $88(11.3)$ & $5.5(2.1-3.6)$ & 86 & $4(4.7)$ & $1.1(0.1-10.5)$ \\
\hline Unemployed & 407 & $63(15.5)$ & $7.2(3.1-17.0)$ & 366 & $56(15.3)$ & 7.7 (3.1-19.6) & 41 & $7(17.1)$ & $4.7(0.6-41.1)$ \\
\hline Laborer & 392 & $117(29.9)$ & $16.8(7.3-38.8)$ & 339 & $109(32.2)$ & $20.3(8.1-50.7)$ & 53 & $8(15.1)$ & $4.1(0.5-34.7)$ \\
\hline Trader & 133 & $33(24.8)$ & $13.0(5.23-32.0)$ & 123 & $31(25.2)$ & $14.4(5.4-38.3)$ & 10 & $2(20.0)$ & $5.8(0.5-72.2)$ \\
\hline Other & 191 & $36(18.9)$ & $9.1(3.8-22.3)$ & 179 & $35(19.6)$ & $10.4(4.0-27.2)$ & 12 & $1(8.3)$ & $2.1(0.1-36.6)$ \\
\hline \multicolumn{10}{|c|}{ Ever injected drugs, lifetime } \\
\hline Never & 1352 & $38(2.8)$ & 1.0 & 1180 & $31(2.6)$ & 1.0 & 172 & $7(4.1)$ & 1.0 \\
\hline Ever & 879 & $309(35.2)$ & $18.8(13.2-26.6)$ & 825 & $293(35.5)$ & $20.4(13.9-30.0)$ & 54 & $16(29.6)$ & $9.9(3.8-25.8)$ \\
\hline
\end{tabular}

OR, odds ratio; CI, confidence interval. Statistically significant associations $(p<0.05)$ are depicted in bold.

\section{Results}

\subsection{Study subjects}

Overall 347 of the 2231 participants (15.6\%) were HIV-1 seropositive at the time of enrollment (Table 1$)$. HIV-1 prevalence among those who had ever injected (35.2\%, $N=879$ ) was markedly higher than among those who had never injected $(2.8 \%, N=1352)$ (OR 18.8, 95\% CI 13.2-26.6). There was higher sero-prevalence among men as compared to women (OR 1.7, 95\% CI 1.1-2.7). Among male participants, other sociodemographic characteristics statistically significantly associated with increased risk for HIV infection included being of Thai ethnicity (compared with ethnic minorities), being between 24 and 34 years old, and having received only primary school education or less. Men who described themselves as students or who were married were also at lower risk for HIV infection. Among female participants, the factors associated with increased risk of HIV infection were being separated, divorced or widowed, or having a history of injection drug use.

\subsection{HIV subtyping and genetic diversity}

Of all the HIV positive individuals in the cohort it was possible to identify the genotype in 336 (97\%) of 347 cases (Table 2). CRF01_AE was the predominant clade, accounting for over $80 \%$ of the strains. Thirteen specimens (3.9\%) were typed as subtype B, and no sample was typed as subtype $C$. Inter-subtype recombinants were abundant, accounting for $9.2 \%$ of the cases, and were
Table 2

Summary of HIV subtypes of the OUR prevalent cohort.

\begin{tabular}{llll}
\hline & IDUs & Non-IDUs & Total \\
\hline Total no. & 309 & 38 & 347 \\
Subtyped, $n(\%)$ & $299(96.8)$ & $37(97.4)$ & $336(96.8)$ \\
Pure subtype/CRF & & & \\
Subtype B, $n(\%)$ & $12(4.0)$ & $1(2.7)$ & $13(3.9)$ \\
Subtype C, $n(\%)$ & $0(0.0)$ & $0(0.0)$ & $0(0.0)$ \\
CRF01_AE, $n(\%)$ & $243(81.3)$ & $32(86.5)$ & $275(81.8)$ \\
Recombinants & & & \\
B/CRF01_AE, $n(\%)$ & $27(9.0)$ & $2(5.4)$ & $29(8.6)$ \\
C/CRF01_AE, $n(\%)$ & $1(0.3)$ & $0(0.0)$ & $1(0.3)$ \\
B/C $n(\%)$ & $1(0.3)$ & $0(0.0)$ & $13(3.9)$ \\
Dual infections & & & $3(0.9)$ \\
B/CRF01_AE, $n(\%)$ & $13(4.3)$ & $0(0.0)$ & $1(0.3)$ \\
C/CRF01_AE, $n(\%)$ & $1(0.3)$ & $2(5.4)$ & $0(0.0)$ \\
B/C, $n(\%)$ & $1(0.3)$ & & \\
\hline
\end{tabular}

mostly due to recombinants combining CRF01_AE with subtype B. Seventeen individuals (5.1\%) carried dual infections, predominantly between subtype B and CRF01_AE; subtype C/CRF01_AE and subtype $\mathrm{B} / \mathrm{C}$ co-infections were also recorded, but rarely.

The majority of the HIV infections in the current cohort (84.4\%) were seen among male IDUs. The observed genetic diversity was evenly distributed among IDUs and non-IDUs, and exhibited no gender bias. Because of the limited number of HIV-infected women and non-IDU patients, we limited the remaining statistical analyses to IDU men. 
Table 3

Comparison of age, ethnicity, and injection duration across subtype B vs. CRF01_AE, among HIV-infected male IDUs in OUR prevalent cohort.

\begin{tabular}{|c|c|c|c|c|}
\hline \multirow[t]{2}{*}{ Variable } & \multicolumn{2}{|l|}{ Subtype/CRF } & \multirow[t]{2}{*}{$p$-Value } & \multirow[t]{2}{*}{ OR $(95 \% \mathrm{CI})$} \\
\hline & CRF01_AE, $N(\%)$ & $\mathrm{B}, N(\%)$ & & \\
\hline Total & $231(100.0)$ & $11(100.0)$ & & \\
\hline \multicolumn{5}{|l|}{ Age (years) } \\
\hline $15-34$ & $180(77.9)$ & $4(36.4)$ & $0.005^{*}$ & 1.0 \\
\hline $35+$ & $51(22.1)$ & $7(63.6)$ & & $6.2(1.7-21.9)$ \\
\hline \multicolumn{5}{|l|}{ Ethnicity } \\
\hline Thai & $158(68.4)$ & $10(90.9)$ & $0.18^{*}$ & 1.0 \\
\hline Ethnic minority & $73(31.6)$ & $1(9.1)$ & & $0.2(0.03-1.7)$ \\
\hline \multicolumn{5}{|c|}{ Number years been injecting } \\
\hline Less than 6 years & $103(44.6)$ & $1(9.1)$ & $0.03^{*}$ & 1.0 \\
\hline $6+$ & $128(55.4)$ & $10(90.9)$ & & $8.1(1.0-63.9)$ \\
\hline
\end{tabular}

* Fisher's Exact Test two-sided $p$-value.

\subsection{Socio-demographic variables and genetic diversity}

Table 3 shows an unadjusted comparison of socio-demographic and injection factors between the two principal HIV clades, CRF01 AE and subtype B. Compared to those with CRF01 AE, individuals with subtype $B$ were more likely to be 35 years of age or older (OR 6.2, 95\% CI 1.7-21.9), and more likely to have injected drugs for 6 years or more (OR 8.1, 95\% CI 1.0-63.9).

An analysis of socio-demographic and behavioral factors associated with dual infection is presented in Table 4. In the crude analysis, individuals with dual infections were more likely to have an increased frequency of sharing needle/syringe (OR 6.0, 95\% CI 1.3-27.1), initiated injecting in the last three years (OR 4.5, 95\% CI 1.2-16.7), and had a lower education level (OR 4.2, 95\% CI 1.2-15.5). These associations remained statistically significant after separate adjustments for age and for education: increased frequency of sharing needle/syringe (age-adjusted OR 6.1, 95\% CI 1.3-28.3; education-adjusted OR 7.0, 95\% CI 1.5-34.1), having initiated injecting in the last three years (age-adjusted OR 5.2, 95\% CI 1.3-20.8; education-adjusted OR 3.9, 95\% CI 1.1-14.6), and having a lower educational level (age-adjusted OR 5.2, 95\% CI 1.4-20.3).

Those individuals who reported ever having sexual intercourse were less likely to have a dual infection, although this was not statistically significant (OR $0.2,95 \%$ CI $0.1-1.2$ ). No other statistical associations or trends were found between exposure variables and dual infection.

In a further analysis (data not shown), dual and recombinant infection were combined together as "complex" infection and compared to single clade infections without recombination. Complex infections were associated with an increased frequency of needle/syringe sharing (age-adjusted OR 5.3, 95\% CI 1.6-17.1).

\section{Discussion}

In this cohort of drug users in Northern Thailand, we show that HIV genetic diversity is increasing and is associated with certain high-risk behaviors and demographic factors. Frequent needle sharing was associated with both dual and recombinant HIV infection. Recent injection of drugs and lower education were significantly associated with dual HIV infection.

Our findings are consistent with several previous studies that show increasing HIV genetic diversity in the Thai IDU population. In our study, four out of five HIV-1 infections were due to CRF01_AE. Inter-subtype recombinants outnumbered subtype B strains. Individuals with subtype B were on average older and had been injecting drugs longer than those with CRF01 $A E$, reflecting the evolution of the HIV epidemic in this population (Tovanabutra et al., 2004).

Overall, 5.1\% (17 of 336) individuals carried dual infections, a rate substantially higher than has been reported from other population samples (Hu et al., 2005). This is one of the first IDU cohorts in which an estimation of the prevalence of dual infection has been possible and therefore few studies are available for direct comparison. Of interest, in Thailand a study amongst 126 seroconverting IDUs found, using restriction-fragment length polymorphism (RFLP) analysis of the HIV protease, that 2/80 individuals (2.5\%) had dual infections in the year following primary HIV infection (Hu et al., 2005). By interrogating eight different regions throughout the HIV genome, the current use of MHAbce may provide a higher sensitivity for the study of dual infection. Of note, both RFLP and MHAbce can only detect dual infections when these are due to different clades but are insensitive to dual infections with the same clade. The high proportion of dual infections seen in our cohort of intravenous drug users is biologically plausible. Injecting the virus into the blood is an efficient mode of HIV transmission, as no mucosal barriers need to be overcome. In addition, individuals who inject drugs and share needles and other injecting equipment likely have multiple exposures to HIV and other blood-borne pathogens.

Sexual exposure was not associated with dual infection in this population. This is likely related to the finding that this is a relatively sexually low risk population with primary HIV acquisition risks related to injecting practices. Studies among individuals with multiple and high risk sexual exposure histories (such as sex workers or persons with other multiple partnership patterns) would be needed to explore the phenomenon we have described here among injectors.

The primary aim of this study was to assess factors amongst IDUs associated with increased genetic diversity. The principal finding was that increased frequency of needle sharing is associated with much higher rates of dual infection and recombination. Although mathematical modeling studies have suggested that this may be an important risk factor (Xiridou et al., 2007), our study is the first of its nature to demonstrate this empirically. Sharing of needles is associated with multiple exposures to HIV. This increases the opportunity of dual infection and recombination, as each exposure facilitates transmission of different HIV-1 strains. Other factors found to be associated with dual infection (recent injection drug use and low education level) are also likely to be associated with increased HIV exposure. Sexual risk factors were not associated with dual or recombinant infection, suggesting it is intravenous drug use rather than sexual exposure, which is responsible for the increasing genetic diversity of HIV.

Needle exchange programs have been piloted in Thailand for some years but widespread implementation has proven difficult (Kerr et al., 2007). This study shows that such programs could represent a major intervention to limit the genetic diversity of the epidemic and should be implemented. Increasing access to sterile injection equipment (available through pharmacies in Thailand), providing education on needle hygiene through outreach, and 
Table 4

Crude and age- and education-adjusted odds ratios comparing dual vs. single infection among male IDU.

\begin{tabular}{|c|c|c|c|c|c|c|c|}
\hline Variable & Total, $N$ & $\begin{array}{l}\text { Single infections }{ }^{\mathrm{a}} \\
N(\%)\end{array}$ & $\begin{array}{l}\text { Dual infections }{ }^{\mathrm{b}} \\
N(\%)\end{array}$ & $\begin{array}{l}\text { Crude OR ( } 95 \% \mathrm{CI} \text { ) } \\
\text { (dual vs. single) }\end{array}$ & Chi-sq $p$-value & $\begin{array}{l}\text { Age-adjusted OR } \\
(95 \% \mathrm{CI})\end{array}$ & $\begin{array}{l}\text { Education-adjusted } \\
\text { OR }(95 \% \mathrm{CI})\end{array}$ \\
\hline Total HIV+ Male IDUs & 283 & $269(100.0)$ & $14(100.0)$ & & & & \\
\hline \multicolumn{8}{|l|}{ Age (years) } \\
\hline $15-23$ & 67 & $63(23.4)$ & $4(28.6)$ & $1.4(0.3-6.4)$ & $0.98^{*}$ & & \\
\hline $24-29$ & 84 & $80(29.7)$ & $4(28.6)$ & $1.1(0.2-5.0)$ & & & \\
\hline $30-34$ & 64 & $61(22.7)$ & $2(21.4)$ & $1.1(0.2-5.5)$ & & & \\
\hline $35+$ & 68 & $65(24.2)$ & $3(21.4)$ & 1.0 & & & \\
\hline \multicolumn{8}{|l|}{ Ethnicity } \\
\hline Thai & 198 & $189(70.3)$ & $9(64.3)$ & 1.0 & & & \\
\hline Ethnic minority & 85 & $80(29.7)$ & $5(35.7)$ & $1.3(0.4-4.0)$ & $0.77^{*}$ & & \\
\hline \multicolumn{8}{|l|}{ Education level } \\
\hline Primary school or less & 136 & $125(46.5)$ & $11(78.6)$ & $4.2(1.2-15.5)$ & 0.02 & $5.2(1.4-20.3)$ & \\
\hline Secondary school or more & 147 & $144(53.5)$ & $3(21.4)$ & 1.0 & & 1.0 & \\
\hline \multicolumn{8}{|l|}{ Occupation } \\
\hline Unemployed & 51 & $48(17.8)$ & $3(21.4)$ & 1.0 & & & \\
\hline Farmer/gardener & 72 & $70(26.0)$ & $2(14.3)$ & $0.5(0.1-2.8)$ & & & \\
\hline Other & 160 & $151(56.1)$ & $9(64.3)$ & $1.0(0.6-1.5)$ & $0.70^{*}$ & & \\
\hline \multicolumn{8}{|l|}{ Marital status } \\
\hline Ever married & 142 & $133(49.4)$ & $9(64.3)$ & 1.0 & & & \\
\hline Never married & 141 & $136(50.6)$ & $5(35.7)$ & $0.5(0.2-1.7)$ & 0.28 & & \\
\hline \multicolumn{8}{|c|}{ Province where currently reside } \\
\hline Chiang Rai & 56 & $54(20.1)$ & $2(14.3)$ & 1.0 & & & \\
\hline Chiang Mai & 184 & $173(64.3)$ & $11(78.6)$ & $1.7(0.4-8.0)$ & & & \\
\hline Other & 43 & $42(15.6)$ & $1(7.1)$ & $0.6(0.1-7.3)$ & $0.72^{*}$ & & \\
\hline \multicolumn{8}{|c|}{ Ever been incarcerated or jailed, lifetime } \\
\hline No & 77 & $73(27.1)$ & $4(28.6)$ & 1.0 & & & \\
\hline Yes & 206 & $196(72.9)$ & $10(71.4)$ & $0.9(0.3-3.1)$ & $1.00^{*}$ & & \\
\hline \multicolumn{8}{|c|}{ Number of years been injecting } \\
\hline Less than 3 years & 57 & $51(19.0)$ & $6(42.9)$ & $4.5(1.2-16.7)$ & $0.04^{*}$ & $5.2(1.3-20.8)$ & $3.9(1.1-14.6)$ \\
\hline $3-5$ & 68 & $64(23.8)$ & $4(28.6)$ & $2.4(0.6-9.9)$ & & $2.8(0.6-12.5)$ & $2.4(0.6-10.1)$ \\
\hline $6+$ & 158 & $154(57.2)$ & $4(28.6)$ & 1.0 & & 1.0 & 1.0 \\
\hline \multicolumn{8}{|l|}{ Injected in the past 3 months } \\
\hline No & 14 & $14(5.2)$ & 0 & & & & \\
\hline Yes & 269 & $255(94.8)$ & $14(100.0)$ & $\mathrm{n} / \mathrm{a}$ & & & \\
\hline \multicolumn{8}{|c|}{ Frequency of injecting drugs, past 3 months $(n=269)$} \\
\hline$<$ Daily & 60 & $57(22.4)$ & $3(21.4)$ & 1.0 & & & \\
\hline Daily & 209 & $198(77.7)$ & $11(78.6)$ & $1.1(0.3-3.9)$ & $1.00^{*}$ & & \\
\hline \multicolumn{8}{|c|}{ Have you ever shared needle/syringe, lifetime? } \\
\hline No & 43 & $40(14.9)$ & $3(21.4)$ & 1.0 & & & \\
\hline Yes & 240 & $229(85.1)$ & $11(78.6)$ & $0.6(0.2-2.4)$ & $0.45^{*}$ & & \\
\hline \multicolumn{8}{|c|}{ Have you shared needle/syringe, past 3 months? $(n=269)$} \\
\hline No & 118 & $113(44.3)$ & $5(35.7)$ & 1.0 & & & \\
\hline Yes & 151 & $142(55.7)$ & $9(64.3)$ & $1.4(0.5-4.4)$ & 0.53 & & \\
\hline \multicolumn{8}{|c|}{ Number (on average) of other people shared needle/syringe with, past 3 months $(n=151)$} \\
\hline One other injector & 84 & $80(56.3)$ & $4(44.4)$ & 1.0 & & & \\
\hline 2 or more others & 67 & $62(43.7)$ & $5(55.6)$ & $1.6(0.4-6.3)$ & $0.51^{*}$ & & \\
\hline Frequency of sharing needle & yringe wit & thers, past 3 month & $n=151)$ & & & & \\
\hline Half the time or less & 137 & $131(92.3)$ & $6(66.7)$ & 1.0 & & 1.0 & 1.0 \\
\hline More than half the time & 14 & $11(7.7)$ & $3(33.3)$ & $6.0(1.3-27.1)$ & $0.04^{*}$ & $6.1(1.3-28.2)$ & $7.0(1.5-34.1)$ \\
\hline Ever had sexual intercourse & fetime & & & & & & \\
\hline No & 12 & $10(3.7)$ & $2(14.3)$ & 1.0 & & & \\
\hline Yes & 271 & $259(96.3)$ & $12(85.7)$ & $0.2(0.1-1.2)$ & $0.11^{*}$ & & \\
\hline Number of sexual partners, & etime $(n=$ & & & & & & \\
\hline 1-9 sexual partners & 129 & $121(46.7)$ & $8(66.7)$ & 1.0 & & & \\
\hline $10+$ & 142 & $138(53.3)$ & $4(33.3)$ & $0.4(0.1-1.5)$ & 0.18 & & \\
\hline Ever had sex with a female & $x$ worker, $l$ & time $(n=271)$ & & & & & \\
\hline No & 80 & $78(30.1)$ & $2(16.7)$ & 1.0 & & & \\
\hline Yes & 191 & $181(69.9)$ & $10(83.3)$ & $2.2(0.5-10.1)$ & $0.52^{*}$ & & \\
\hline Ever had sex with another $n$ & , lifetime & $=271)$ & & & & & \\
\hline No & 252 & $240(92.7)$ & $12(100.0)$ & & & & \\
\hline Yes & 19 & $19(7.3)$ & 0 & $\mathrm{n} / \mathrm{a}$ & & & \\
\hline Any lab-diagnosed STD (Syp & illis, Chlam & dia and/or Gonorrhe & $(n=271)$ & & & & \\
\hline No & 255 & $243(93.8)$ & $12(100.0)$ & & & & \\
\hline Yes & 16 & $16(6.2)$ & 0 & $\mathrm{n} / \mathrm{a}$ & & & \\
\hline
\end{tabular}

a Single infection $=$ CRF01 AE, subtype B, subtype C, B/CRF01_AE Recombinant, C/CRF01_AE Recombinant, or B/C Recombinant.

b Dual infection = B/CRF01_AE Dual, C/CRF01_AE Dual, or B/C Dual.

* Fisher's Exact Test two-sided $p$-value.

increasing access to drug treatment services will all be helpful in reducing harm associated with HIV acquisition and transmission.

As found in other studies we found significantly lower rates of HIV infection among drug users who reported never had injected drugs (Beyrer et al., 2004). While increased sexual risk-taking has been associated with HIV acquisition among non-injecting drug users in other settings, we found very low rates of HIV among these cohort participants, most of whom were methamphetamine smokers. 
Dual infection and recombination are major concerns for future vaccine design. Fortunately, current vaccine candidates contain both subtype B and CRF01_AE, and could potentially protect against recombinant strains of the parent viruses. However, such vaccines candidates may not be able to protect against other recombinants (McKinnon et al., 2005; Taylor et al., 2008). A further challenge is that dual HIV infection may increase disease progression (Gottlieb et al., 2004). Recombination may also lead to the development of more difficult to treat variants, as demonstrated by a recent case in the United States (Blick et al., 2007).

There were several limitations to this study. First, the crosssectional nature of the study means causality could not be assessed. Therefore it was not possible to elucidate if acquisition of HIV occurred prior to exposure to social risk factors or vice versa. Second, all information on behavioral risk factors were from self-report and therefore may not be accurate. Third, it was not possible to obtain the subtype of patients for 11 (3.2\%) of the study participants, which could have introduced modest selection bias into the study. However these individuals did not differ significantly in exposure variables to those who were included in the subtype analysis (data not shown). Although the overall cohort was large, the total number of individuals who had dual or recombinant infection was relatively small. As a result it was not possible to analyze differences of genetic diversity between sexes, and in the non-IDU population. Finally, the specimens analyzed were from an earlier phase of the Thai epidemic, and may not reflect the current molecular epidemiology of HIV in this population.

In conclusion, to limit the increasing and expanding complexity of HIV-1 strains in Thailand early intervention should be aimed at reduction in needle sharing, especially among new IDUs. These results highlight how molecular epidemiology can identify those risks most likely to increase the complexity of strains, and so assist with targeting interventions to limit HIV diversity.

\section{Role of funding source}

This work was partly supported by a cooperative agreement between the Henry M Jackson Foundation for the Advancement of Military Medicine and the U.S. Department of Defense, and partly by grants (1 R01 DA 11133, and a competitive supplement from the Office of AIDS Research) from the National Institutes of Health, Bethesda, MD. The views and opinions expressed herein do not necessarily reflect those of the U.S. Army or of the Department of Defense.

The Henry M Jackson Foundation for the Advancement of Military Medicine, the U.S. Department of Defense, and the NIH had no further role in study design; in the collection, analysis and interpretation of data; in the writing of the report; or in the decision to submit the paper for publication.

\section{Contributors}

G.H. Kijak, PharmD, PhD: carried out laboratory work and wrote the first draft of the manuscript. C. Beyrer, MD, MPH: Co-principal investigator of project, executed protocol, wrote the first draft of the manuscript. S. Tovanabutra, PhD: Co-principal investigator of project, executed protocol, carried out laboratory work. T. Sripaipan, MPH: carried out statistical analysis. V. Suriyanon, MD: Principal investigator of project. N. Moqueet, MPH: carried out laboratory work. E. Sanders-Buell, MSc: carried out laboratory work. P. Saokhieo, RN: subject recruitment and enrolment, and sample collection. U. Timpan, BA: subject recruitment and enrolment, and sample collection. J. Jittiwutikarn, MD: Principal investigator of project. M.L. Robb, MD: provided leadership and facilitated the collaboration between the parties. D.L. Birx, MD: provided leadership and facilitated the collaboration between the parties. D.D. Celentano, ScD: principal investigator of project, executed protocol. F.E. McCutchan, PhD: provided leadership and designed molecular experiments.

All authors contributed to and have approved the final manuscript.

\section{Conflict of interest}

\section{All of the authors declare no conflict of interest.}

\section{Acknowledgements}

We are thankful to the subjects who participated in this study, Dr. Myat Htoo Razak, Charintarat Kitisri, and the staff of Research Institute for Health Sciences, Northern Drug Treatment Center, Thailand, for their help collecting specimens, epidemiological data, and laboratory technical assistance.

\section{References}

Arroyo, M.A., Hoelscher, M., Sateren, W., Samky, E., Maboko, L., Hoffmann, O., Kijak G., Robb, M., Birx, D.L., McCutchan, F.E., 2005. HIV-1 diversity and prevalence differ between urban and rural areas in the Mbeya region of Tanzania. AIDS 19, 1517-1524.

Arroyo, M.A., Sateren, W.B., Foglia, G., Kibaya, R., Langat, L., Wasunna, M., Bautista, C.T., Scott, P.T., Shaffer, D.N., Robb, M.L., Michael, N.L., Birx, D.L., McCutchan, F.E., 2009. Short communication: HIV type 1 genetic diversity among tea plantation workers in Kericho, Kenya. AIDS Res. Hum. Retroviruses 25, 1061-1064.

Arroyo, M.A., Sateren, W.B., Serwadda, D., Gray, R.H., Wawer, M.J., Sewankambo, N.K., Kiwanuka, N., Kigozi, G., Wabwire-Mangen, F., Eller, M., Eller, L.A., Birx, D.L., Robb, M.L., McCutchan, F.E., 2006. Higher HIV-1 incidence and genetic complexity along main roads in Rakai District, Uganda. J. Acquir. Immune Defic. Syndr. 43, 440-445.

Beyrer, C., Artenstein, A., Kunawararak, P., VanCott, T., Mason, C., Rungreungthanakit K., Hegerich, P., Nelson, K.E., Khamboonruang, C., Natpratan, C., 1997. The molecular epidemiology of HIV-1 among male sex workers in northern Thailand. J. Acquir. Immune Defic. Syndr. Hum. Retrovirol. 15, 304-307.

Beyrer, C., Razak, M.H., Jittiwutikarn, J., Suriyanon, V., Vongchak, T., Srirak, N., Kawichai, S., Tovanabutra, S., Rungruengthanakit, K., Sawanpanyalert, P., Sripaipan, T., Celentano, D.D., 2004. Methamphetamine users in northern Thailand: changing demographics and risks for HIV and STD among treatment-seeking substance abusers. Int. J STD AIDS 15, 697-704.

Blick, G., Kagan, R.M., Coakley, E., Petropoulos, C., Maroldo, L., Greiger-Zanlungo, P., Gretz, S., Garton, T., 2007. The probable source of both the primary multidrugresistant (MDR) HIV-1 strain found in a patient with rapid progression to AIDS and a second recombinant MDR strain found in a chronically HIV-1-infected patient. J. Infect. Dis. 195, 1250-1259.

Bunnik, E.M., Euler, Z., Welkers, M.R., Boeser-Nunnink, B.D., Grijsen, M.L., Prins, J.M., Schuitemaker, H., 2010. Adaptation of HIV-1 envelope gp120 to humoral immunity at a population level. Nat. Med. 16, 995-997.

Cheng, Y., Sherman, S.G., Srirat, N., Vongchak, T., Kawichai, S., Jittiwutikarn, J., Suriyanon, V., Razak, M.H., Sripaipan, T., Celentano, D.D., 2006. Risk factors associated with injection initiation among drug users in Northern Thailand. Harm Reduct. J. 3, 10.

Deewong, S., Jitnumshap, P., 2003. Situation of AIDS and symptomatic HIV infection cases in Thailand at January 31, 2003. Weekly Epidemiology Surveillance Report, vol. 34, pp. 165-167.

Djoko, C.F., Wolfe, N.D., Vidal, N., Tamoufe, U., Montavon, C., LeBreton, M., Pike, B.L., Fair, J., Mbacham, W.F., Benito, A., Rimoin, A.W., Saylors, K., Mpoudi-Ngole, E., Grillo, M.P., Peeters, M., 2010. HIV type 1 pol gene diversity and genotypic antiretroviral drug resistance mutations in Malabo, Equatorial Guinea. AIDS Res. Hum. Retroviruses 26, 1027-1031.

Gottlieb, G.S., Nickle, D.C., Jensen, M.A., Wong, K.G., Grobler, J., Li, F., Liu, S.L., Rademeyer, C., Learn, G.H., Karim, S.S., Williamson, C., Corey, L., Margolick, J.B., Mullins, J.I., 2004. Dual HIV-1 infection associated with rapid disease progression. Lancet 363, 619-622.

Herbinger, K.H., Gerhardt, M., Piyasirisilp, S., Mloka, D., Arroyo, M.A., Hoffmann, O. Maboko, L., Birx, D.L., Mmbando, D., McCutchan, F.E., Hoelscher, M., 2006. Frequency of HIV type 1 dual infection and HIV diversity: analysis of low- and high-risk populations in Mbeya Region, Tanzania. AIDS Res. Hum. Retroviruses 22, 599-606.

Hoelscher, M., Dowling, W.E., Sanders-Buell, E., Carr, J.K., Harris, M.E., Thomschke, A., Robb, M.L., Birx, D.L., McCutchan, F.E., 2002. Detection of HIV-1 subtypes, recombinants, and dual infections in east Africa by a multi-region hybridization assay. AIDS 16, 2055-2064.

Hu, D.J., Subbarao, S., Vanichseni, S., Mock, P.A., Ramos, A., Nguyen, L., Chaowanachan, T., Griensven, F., Choopanya, K., Mastro, T.D., Tappero, J.W., 2005. 
Frequency of HIV-1 dual subtype infections, including intersubtype superinfections, among injection drug users in Bangkok, Thailand. AIDS 19, 303-308.

Kerr, T., Kaplan, K., Suwannawaong, P., Wood, E., 2007. Health and human rights in the midst of a drug war. The Thai drug users' network. In: Beyrer, C., Pizer, H. (Eds.), Public Health and Human Rights 2007. Johns Hopkins University Press.

Kijak, G.H., Tovanabutra, S., Sanders-Buell, E., Watanaveeradej, V., de Souza, M.S., Nelson, K.E., Ketsararat, V., Gulgolgarn, V., Wera-arpachai, M., Sriplienchan, S., Khamboonrueng, C., Birx, D.L., Robb, M.L., McCutchan, F.E., 2007. Distinguishing molecular forms of HIV-1 in Asia with a high-throughput, fluorescent genotyping assay, MHAbce v.2. Virology 358, 178-191.

Kuiken, C., Leitner, T., Foley, B., Hahn, B., Marx, P., McCutchan, F., Wolinsky, S., Korber, B., 2009. HIV Sequence Compendium 2009. Los Alamos National Laboratory Theoretical Biology and Biophysics, Los Alamos, NM.

McKinnon, L.R., Ball, T.B., Kimani, J., Wachihi, C., Matu, L., Luo, M., Embree, J., Fowke, K.R., Plummer, F.A., 2005. Cross-clade CD8(+) T-cell responses with a preference for the predominant circulating clade. J. Acquir. Immune Defic. Syndr. 40, $245-249$.

Ramos, A., Hu, D.J., Nguyen, L., Phan, K.O., Vanichseni, S., Promadej, N., Choopanya, K., Callahan, M., Young, N.L., McNicholl, J., Mastro, T.D., Folks, T.M., Subbarao, S., 2002. Intersubtype human immunodeficiency virus type 1 superinfection following seroconversion to primary infection in two injection drug users. J. Virol. 76, 7444-7452.

Razak, M.H., Jittiwutikarn, J., Suriyanon, V., Vongchak, T., Srirak, N., Beyrer, C., Kawichai, S., Tovanabutra, S., Rungruengthanakit, K., Sawanpanyalert, P., Celentano, D.D., 2003. HIV prevalence and risks among injection and noninjection drug users in northern Thailand: need for comprehensive HIV prevention programs. J. Acquir. Immune Defic. Syndr. 33, 259-266.

Saathoff, E., Pritsch, M., Geldmacher, C., Hoffmann, O., Koehler, R.N., Maboko, L., Maganga, L., Geis, S., McCutchan, F.E., Kijak, G.H., Kim, J.H., Arroyo, M.A., Gerhardt, M., Tovanabutra, S., Robb, M.L., Williamson, C., Michael, N.L., Hoelscher, M., 2010. Viral and host factors associated with the HIV-1 viral load setpoint in adults from Mbeya Region, Tanzania. J. Acquir. Immune Defic. Syndr. 54, 324-330.
Smith, D.M., Richman, D.D., Little, S.J., 2005. HIV superinfection. J. Infect. Dis. 192, $438-444$.

Subbarao, S., Limpakarnjanarat, K., Mastro, T.D., Bhumisawasdi, J., Warachit, P., Jayavasu, C., Young, N.L., Luo, C.C., Shaffer, N., Kalish, M.L., Schochetman, G., 1998. HIV type 1 in Thailand, 1994-1995: persistence of two subtypes with low genetic diversity. AIDS Res. Hum. Retroviruses 14, 319-327.

Taylor, B.S., Sobieszczyk, M.E., McCutchan, F.E., Hammer, S.M., 2008. The challenge of HIV-1 subtype diversity. N. Engl. J. Med. 358, 1590-1602.

Tovanabutra, S., Beyrer, C., Sakkhachornphop, S., Razak, M.H., Ramos, G.L., Vongchak, T., Rungruengthanakit, K., Saokhieo, P., Tejafong, K., Kim, B., De Souza, M., Robb, M.L., Birx, D.L., Jittiwutikarn, J., Suriyanon, V., Celentano, D.D., McCutchan, F.E., 2004. The changing molecular epidemiology of HIV type 1 among northern Thai drug users, 1999 to 2002. AIDS Res. Hum. Retroviruses 20, 465-475.

Tovanabutra, S., Kijak, G.H., Beyrer, C., Gammon-Richardson, C., Sakkhachornphop, S., Vongchak, T., Jittiwutikarn, J., Razak, M.H., Sanders-Buell, E., Robb, M.L., Suriyanon, V., Birx, D.L., Michael, N.L., Celentano, D.D., McCutchan, F.E., 2007. Identification of CRF34_01B, a second circulating recombinant form unrelated to and more complex than CRF15_01B, among injecting drug users in northern Thailand. AIDS Res. Hum. Retroviruses 23, 829-833.

Tovanabutra, S., Polonis, V., De Souza, M., Trichavaroj, R., Chanbancherd, P., Kim, B., Sanders-Buell, E., Nitayaphan, S., Brown, A., Robb, M.R., Birx, D.L., McCutchan, F.E., Carr, J.K., 2001. First CRF01_AE/B recombinant of HIV-1 is found in Thailand. AIDS 15, 1063-1065.

Vanichseni, S., Kitayaporn, D., Mastro, T.D., Mock, P.A., Raktham, S., Des Jarlais, D.C., Sujarita, S., Srisuwanvilai, L.O., Young, N.L., Wasi, C., Subbarao, S., Heyward, W.L., Esparza, L., Choopanya, K., 2001. Continued high HIV-1 incidence in a vaccine trial preparatory cohort of injection drug users in Bangkok, Thailand. AIDS 15, 397-405.

Xiridou, M., van Griensven, F., Tappero, J.W., Martin, M., Gurwith, M., Vanichseni, S., Kittikraisak, W., Coutinho, R., Choopanya, K., 2007. The spread of HIV-1 subtypes $\mathrm{B}$ and CRF01_AE among injecting drug users in Bangkok, Thailand. J. Acquir. Immune Defic. Syndr. 45, 468-475. 